Journal of Sport Coaching and Physical Education 3 (1) (2018)

\title{
TRACER STUDY RELEVANSI KOMPETENSI LULUSAN PROGRAM STUDI PENDIDIKAN KEPELATIHAN OLAHRAGA DENGAN KEBUTUHAN LAPANGAN KERJA
}

\section{Soedjatmiko}

Jurusan Pendidikan dan Kepelatihan Olahraga, Fakultas Ilmu Keolahragaan, Universitas Negeri Semarang, Indonesia

\section{Info Artikel}

Sejarah Artikel:

Diterima Mei 2018

Disetujui Juni 2018

Dipublikasikan Agustus 2018

Keywords: Alumni, Relevansi, Kompetensi

\begin{abstract}
Abstrak
Jenis penelitian ini adalah penelitian kuantitatif dengan desain riset deskriptif kuantitatif. Desain deskriptif kuantitatif bertujuan untuk menjelaskan sesuatu, seperti : menjelaskan suatu kelompok yang relevan. Populasi penelitian ini adalah seluruh mahasiswa lulusan Prodi PKLO yang lulus sepuluh tahun terakhir yaitu antara 2007 sampai 2017 yang telah bekerja. Sedangkan sampel yang diambil adalah masing-masing 10 alumni pada tiap tahun kelulusan. Metode pengumpulan data menggunakan kuesioner yang disampaikan melalui email attachment maupun dikirim melalui pos dalam bentuk hard copy. Dari analisis data diperoleh data 1) usia responden yang mengisi kuesioner sebanyak 69,8 persen berusia dibawah 30 tahun, sisanya 30,2 \% berusia 30 tahun ke atas. Alamat responden sebanyak $52 \%$ tinggal di karesidenan Semarang dan Karesidenan pekalongan. Sisanya sebesar 48 \% tinggal di karesidenan pati, Banyumas, Tegal dan luar Jawa Tengah. Lama masa studi responden didapat hasil sebesar 53,8 \% lulus 4 tahun atau kurang. Sisanya 46,2 \% lulus setelah 4 tahun dan hanya 4,8\% yang lulus lebih dari 5 tahun. Untuk jenis pekerjaan mayoritas responden atau sebesar 71,4\% menjadi guru/dosen, 12,7 \% bekerja di bidang lain serta 15,9\% belum bekerja. Selanjutnya untuk masa tunggu lulusan didapat data sebanyak 49,2 \% memperoleh pekerjaan dalam kurun waktu 0 sampai 11 bulan, yang memperoleh pekerjaan antara 11 sampai 23 bulan sebanyak 36,5\% dan yang memperoleh pekerjaan dua tahun lebih sebesar 14,3\%. Simpulan sebagai berikut : 1) Hasil penelitian tracer study ini didapat data tentang alumni yang terdiri dari jenis pekerjaan, lama studi, lama masa tunggu pekerjaan, relevansi kurikulum dan pekerjaan serta maasukan dari Alumni. 2). Mayoritas responden mengusulkan ada penelitian tentang tracer study yang diadakan secara berkala agar mereka dapat menyumbangkan tenaga dan pikirannya. 3) Mayoritas responden mengusulkan adanya rekonstruksi kurikulum agar Program studi selalu dapat mengembangkan diri dan dapat menjawab tantangan perkembangan jaman. 4) Program studi Pendidikan Kepelatihan Olahraga sangat membutuhkan Tracer Study untuk mendapatkan umpan balik dari alumninya dan dari stake holder lulusan.
\end{abstract}




\section{PENDAHULUAN}

Penelusuran alumni dapat dilakukan oleh universitas, namun juga dapat dilakukan oleh fakultas maupun jurusan atau program studi.Penelusuran dapat dilakukan pada satu tahun lulusan, lima tahun lulusan atau bahkan sepuluh tahun lulusan. Metode yang digunakan untuk mendapatkan dapat dilakukan dengan wawancara, dokumentasi, kuesioner serta metode lainya. Sedangkan penyampaian kuesioner dapat dilakukan melalui website, email attachment maupun disampaikan secara langsung.

Evaluasi diri yang baik harus dilakukan secara menyeluruh dan dilakukan secara periodik dan berkelanjutan. Sehingga masukan atau umpan balik dapat diperoleh secara periodik dan berkelanjutan pula. Untuk itu penelusuran alumni, pengguna lulusan juga harus dilakukan secara berkelanjutan.

Program Studi Pendidikan Kepelatihan olahraga Fakultas Ilmu Keolahragaan Unnes adalah program studi yang menyelenggarakan pendidikan pada jenjang sarjana atau S1. Program Studi Pendidikan kepelatihan olahraga mempunyai visi menjadi Program Studi yang Berwawasan Konservasi, Berkarakter, Unggul, dan Berkontribusi di Bidang Pendidikan dan Kepelatihan Olahraga.

Prodi pendidikan kepelatihan olahraga (PKO) telah mendapatkan status akreditasi unggul dari Badan Akreditasi Nasional Perguruan Tinggi (BANPT) sesuai dengan keputusan BAN-PT nomor 3386/SK/BAN-PT/Akred/S/IX/2017 tentang Status dan peringkat terakreditasi program studi Pendidikan Kepelatihan Olahraga pada Program Sarjana Universitas Negeri Semarang dengan peringkat A dengan nilai 369 pada tanggal 12 September 2017. Prodi Pendidikan Kepelatihan olahraga juga telah memperoleh sertifikat ISO 9001:2008 pada tanggal 24 November 2011.

Capaian yang diperoleh program studi pendidikan kepelatihan olahraga perlu dipertahankan bahkan ditingkatkan lagi. Peningkatan kualitas lulusan terus dilakukan dengan melibatkan berbagai pihak termasuk para lulusan. Upaya ini dilakukan untuk menjawab tantangan zaman dan perkembangan ilmu pengetahuan dan teknologi.

Untuk menjaga kesinambungan capaian yang telah diraih, perlu dilakukan upaya untuk selalu mengembangkan istitusi yang berkelanjutan. Pengembangan hanya mungkin dilakukan dengan cara evaluasi diri program studi. Evaluasi diri harus dilandasi masukan dari berbagai pihak baik pihak internal maupun pihak eksternal. Pihak internal adalah Pimpinan unviersitas, fakultas dan prodi, Dosen, tenaga kependidikan dan mahasiswa. Sedangkan dari pihak eksternal yaitu alumni dan pengguna lulusan (Stake Holder).

Tracer study Lulusan merupakan kegiatan akademis yang harus dilaksanakan oleh Perguruan Tinggi untuk memepertahankan kualitasnya. Tujuan pelaksanaan tracer studi adalah mampu memperoleh umpan balik (feedback) dari para lulusan dan pengguna lulusan tentang relevansi proses pendidikan yang telah dijalani dengan kemampuan meningkatkan taraf hidup lulusan di masyarakat.

\section{Permasalahan}

Rumusan masalah dalam penelitian ini adalah:

Bagaimana sebaran lulusan Prodi Pendidikan Kepelatihan olahraga berdasarkan tempat pekerjaan?

Apa jenis pekerjaan lulusan program Studi pendidikan kepelatihan olahraga?

Berapa lama masa tunggu lulusan dalam mendapatkan pekerjaan?

Bagaimana relevansi kurikulum, prodi pendidikan kepelatihan olahraga dengan kebuthan masyarakat?

Bagaimanakah kesesuaian kompetensi lulusan dengan kebutuhan lapangan pekerjaan?

\section{PEMBAHASAN}

Program Studi Pendidikan Kepelatihan Olahraga memiliki tujuan sebagai berikut: 1). Menghasilkan lulusan yang bertaqwa kepada Tuhan Yang Maha Esa, berkarakter, berdaya saing tinggi, dan berwawasan konservasi. 2). Mewujudkan pranata pendidikan dan tata kelola yang kredibel, 
akuntabel, dan transparan yang unggul dan berwawasan konservasi. 3). Menghasilkan penelitian yang unggul di bidang pendidikan dan kepelatihan olahraga yang bermanfaat bagi pengembangan ilmu pengetahuan dan teknologi. 4). Memanfaatkan dan menyebarluaskan ilmu pengetahuan dan teknologi di bidang pendidikan dan kepelatihan olahraga yang berwawasan konservasi dan bereputasi internasional. 5). Memiliki mitra strategis di bidang pendidikan dan kepelatihan olahraga dengan lembaga di dalam dan luar negeri untuk mewujudkan lembaga yang bereputasi, kredibel, akuntabel, dan transparan.Lulusan program studi pendidikan kepelatihan olahraga dapat berprofesi sebagai 1). Tenaga pendidik olahraga (Guru PJOK) di sekolah 2). Pelatih olahraga prestasi 3). Instruktur kebugaran 4). Masseur kebugaran dan cidera 5). Anggota TNI 6). Anggota POLRI 7). Manager Klub olahraga 8). Sebagai wasit dan Juri olahraga.

\section{Profil Alumni Prodi Pendidikan Kepelatihan Olahraga}

Berdasarkan data yang dihimpun selama 5 tahun terakhir, dapat diketahui bahwa minat siswa lulusan SMA/MA/SMK untuk melanjutkan studi ke Program Studi Pendidikan Kepelatihan Olahraga S1 FIK UNNES relatif tinggi. Hal ini bisa dilihat dari jumlah pendaftar dengan daya tampungnya yang mencapai rasio rata-rata 1:8.32. Rasio ini juga menunjukkan ketatnya seleksi untuk menjadi mahasiswa Program Studi Pendidikan Kepelatihan Olahraga S1 FIK UNNES. Rasio rata-rata mahasiswa baru regular yang melakukan registrasi dibanding calon mahasiswa baru regular yang lulus seleksi sebesar 1 : 0.93. Rasio rata-rata mahasiswa baru transfer terhadap mahasiswa baru reguler 1 : 0.03 .

Program Studi pendidikan kepelatihan olahraga telah banyak menghasilkan lulusan atau alumni. Mereka tersebar di berbagai profesi baik negeri maupun swasta di Jawa Tengah maupun di luar jawa tengah bahkan luar Jawa. Berapa yang bekerja sebagai guru, berapa yang bekerja sebagai anggota TNI/Polri dan bekerja di instansi lainya. Kesemuanya dapat ditemukan jawabanya melalui penelusuran alumni atau Tracer study.

\section{Penelitian Tracer Study}

Tracer study adalah penelitian mengenai situasi alumni khususnya dalam hal pencarian kerja, situasi kerja, dan pemanfaatan pemerolehan kompetensi selama kuliah. Di negara-negara maju, studi pelacakan jejak alumni adalah studi utama yang telah dilaksanakan secara sistematis, institusional, dan terus menerus.

Tracer study merupakan salah satu metode yang digunakan oleh beberapa perguruan tinggi, khususnya di Indonesia untuk memperoleh umpan balik dari alumni. Umpan balik yang diperoleh dari alumni ini dibutuhkan oleh perguruan tinggi dalam usahanya untuk perbaikan serta pengembangan kualitas dan sistem pendidikan. Umpan balik juga dapat bermanfaat bagi perguruan tinggi untuk memetakan dunia usaha dan industri agar jeda diantara kompetensi yang diperoleh alumni saat kuliah dengan tuntutan dunia kerja dapat diperkecil.

Dalam pelaksanaannya, Tracer study dilaksanakan oleh lembaga yang menjembatani antara perguruan tinggi dengan dunia usaha dan industri. Tracer study perlu dilakukan secara melembaga, terstruktur dan dengan metodologi yang tepat guna memperoleh hasil yang terukur, akurat dan dapat diperbandingkan.

Di Indonesia, pelaksanaan Tracer study umumnya masih terkendala di sisi kebutuhan, sumber daya dan metodologi dalam pelaksanaannya. Seringkali Tracer study dilakukan oleh perguruan tinggi hanya karena kebutuhan akan akreditasi, sehingga pelaksanaannya tidak dilakukan secara rutin. Selain itu, sumber daya pelaksana Tracer study umumnya masih dianggap kurang memadai dan hal ini disertai dengan kesulitan dalam menerapkan metodologi yang tepat dalam pelaksanaannya.

Desain deskriptif bertujuan untuk menjelaskan sesuatu, seperti : menjelaskan suatu kelompok yang relevan, mengestimasi persentase unit dalam populasi tertentu, mengetahui persepsi atas karakteristik produk, mengetahui berapa besar hubungan sautu variabel dan mengetahui prediksi spesifik. (Malhotra, 2007). 
Penelitian yang dilakukan merupakan penelitian yang dilakukan sebanyak satu kali tindakan dalam satu periode (single cross sectional design). Pada penelitian ini, digunakan teknik survey dengan cara menyebarkan kuesioner kepada dimana alumni bekerja. Penyampaian kuesioner dilakukan dengan dua cara yaitu diberikan langsung kuesioner tersebut dan yang kedua melaui email attachment.

Desain kuesioner yang dipergunakan peneliti pada penelitian ini adalah sebagai berikut. 1). Close Ended Quation yaitu bentuk pertanyaan dengan beberapa alternative pilihan, dimana Pengguna harus memilih salah satu pilihan yang ada. Pertanyaan ini ada pada profil responden. 2). Open Question yaitu bentuk pertanyaan dengan membebaskan pengisi questioner untuk menjawab pertanyaan yang ada. Tanpa adanya pilihan yang mengikat. 3). Scale Respon Question Bentuk pertanyaan yang menggunakan scala dalam pengukuran dan bertujuan untuk mengetahui sikap responden terhadap pertanyaan pertanyaan di kuesioner dari sudut pandang responden. Dalam penelitian ini menggunakan modifikasi skala linkert untuk menilai kinerja. Skala linkert untuk menilai kinerja dibagi menjadi empat tingkatan yaitu 1 . Sangat penting tidak penting 2. Tidak penting 3 . Penting dan 4. Sangat penting.

Dari 75 buah kuesioner yang dibagikan kembali sebanyak 63 buah. Selanjutnya dari 63 buah kuesioner yang kembali selanjutnya dianalisis dengan analisis deskriptif kuantitatif. Dari analisis data yang dikumpulkan dari responden terkumpullah data identitas umum responden.

Dalam penelitian ini identitas responden dibagi menjadi dua yaitu : identitas Umum dan identitas khusus. Identitas umum berisi nama, alamat, tempat tanggal lahir, nomor telepon dan alamat email. Nama, nomor telepon dan alamat email dipergunakan untuk melakukan komunikasi dengan responden. Sedangkan alamat dan tempat tanggal lahir akan dianalis dan dipetakan alumni berdasarkan usia dan alamat kabupaten dimana responden yang mengisi kuesioner tersebut tinggal.

Identitas khusus terdiri dari tahun masuk, tahun lulus, jenis pekerjaan, mulai bekerja, nama instasi dan nama pimpinan instansi. Tahun masuk dan tahun lulus dianalisis untuk mengetahui berapa tahun mahasiswa tersebut ketika menempuh kuliah pada prodi PKLO. Jenis pekerjaan dibutuhkan untuk mengetahui keselarasan antara ijazah yang dimiliki dengan pekerjaan yang dilakukan saat ini. Mulai bekerja dibutuhkan untuk mengetahui lama masa tunggu alumni yang bersangkutan. Sedangkan nama instansi dan nama pimpinan instansi dipergunakan untuk memastikan data yang diberikan responden benar sesuai kenyataan.

Selanjutnya dari data identitas yang dianalisis diantaranya adalah a). Usia Responden, b) Alamat Responden c. lama Studi, d. Jenis pekerjaan c. lama masa tunggu.

\section{Usia Responden}

Dari data yang diperoleh didapat bahwa usia responden didominasi oleh mahasiswa yang relativ muda dari segi usia. Hal ini dikarenakan kuesioner dikirim melalui email dan yang mengisi dan membalas email yang kembali dari usia 36 tahun dan sebelumnya. Untuk memudahkan penyajian data usia responden dibuat dengan distribusi bergolong. Usia $20-24$ tahun sebanyak 31 orang atau $49,2 \%$. Usia 25 - 29 tahun sebanyak 13 orang atau 20,6\% dan usia 30 tahun ke atas sebanyak 19 orang atau 30,2\%. Untuk lebih jelasnya dapat dilihat dari tabel 1 di bawah ini :

Tabel 1 : Pengolongan Usia Alumni yang menjadi responden Penelitian

\begin{tabular}{lccc}
\hline Usia & Frekuensi & Prosentase & $\begin{array}{c}\text { Prosentase } \\
\text { kumulatif }\end{array}$ \\
Responden & & $49.2 \%$ & $49.2 \%$ \\
20-24 tahun & 31 & 20.6 & $69,8 \%$ \\
25-29 tahun & 13 & 30,2 & $100 \%$ \\
30 tahun ke & 19 & $100 \%$ & $100 \%$ \\
$\begin{array}{l}\text { atas } \\
\text { Jumlah }\end{array}$ & 63 & & \\
\hline
\end{tabular}

\section{Alamat Responden}

Penyebaran alamat responden tersebar di beberapa kabupaten kota yang ada di Jawa Tengah. Untuk memudahkan pemetaan penelitian ini alamat responden dibagi ke dalam karesidenan yang ada di Jawa Tengah. Karesidenan yang ada di Jawa Tengah ada tujuh karesidenan yaitu a) karesidenan 
Semarang, Karesidenan Pati, c) Karesidenan Pekalongan d) karesidenan Tegal, e) Karesidenan Banyumas, f) karesidenan Kedu dan g) karesidenan Surakarta. Dari hasil analisis dapat disimpulkan sebaran tempat tinggal alumni PKO. Untuk memperjelas akan disajikan pada tabel 2 dibawah ini.

Tabel 2: Sebaran tempat tinggal responden berdasarkan karesidenan

\begin{tabular}{lcc}
\hline \multicolumn{1}{c}{ Karesidenan } & Frekwensi & Prosentase \\
Karesidenan Semarang & 17 & $27 \%$ \\
Karesidenan Pati & 10 & $15.9 \%$ \\
Karesidenan Pekalongan & 17 & $27 \%$ \\
Karesidenan Tegal & 6 & $9.5 \%$ \\
Karesidenan Banyumas & 7 & $11.1 \%$ \\
Luar Jawa Tengah & 6 & $9.5 \%$ \\
$\quad$ Jumlah & 63 & $100 \%$ \\
\hline
\end{tabular}

\section{Lama Studi Reponden}

Lama studi alumni terlihat dari tahun masuk dan bulan dan tahun mereka lulus. Menurut lama studi dibagi menjadi empat golongan/kategori yaitu kurang dari tahun, 4 tahun, 5 tahun dan lebih dari 5 tahun. Agar lebih jelas data akan disajikan pada tabel di bawah ini.

Tabel 3. : Lama studi responden ketika kuliah di Prodi PKO FIK Unnes

\begin{tabular}{|c|c|c|}
\hline Lama Menempuh Studi S1 & Frekwensi & Prosentase \\
\hline Kurang dari 4 tahun & 3 & $4,8 \%$ \\
\hline Empat tahun & 37 & $59 \%$ \\
\hline Lima tahun & 20 & $31.4 \%$ \\
\hline Lebih dari 5 tahun & 3 & $4,8 \%$ \\
\hline Jumlah & 63 & $100 \%$ \\
\hline \multicolumn{3}{|l|}{ Jenis Pekerjaan } \\
\hline \multicolumn{3}{|c|}{$\begin{array}{l}\text { Jenis Pekerjaan alumni terbagi dalam } \\
\text { beberapa jenis pekerjaan. Jenis pemetaan dibagi ke } \\
\text { dalam pekerjaan belum bekerja, sebagai guru, } \\
\text { menjadi dosen, dan Pekerjaan lain. Untuk } \\
\text { memperjelas lihat tabel berikut: } \\
\text { Tabel } 4 \text { : Jenis Pekerjaan Alumni PKO }\end{array}$} \\
\hline Jenis Pekerjaan & Frekwensi & Prosentase \\
\hline Belum Bekerja & 8 & $12,7 \%$ \\
\hline Menjadi Guru Penjasorkes & 35 & $55.5 \%$ \\
\hline Menjadi dosen & 10 & $15.9 \%$ \\
\hline Pekerjaan lain & 10 & $15.9 \%$ \\
\hline Jumlah & 63 & $100 \%$ \\
\hline
\end{tabular}

\section{Masa Tunggu Lulusan}

Masa tunggu lulusan didapatkan data dari tahun yang bersangkutan bekerja dikurangi tahun lulus. Untuk melihat data lama masa tunggu diperlihatkan pada tabel di bawah ini :

Tabel 5: Lama masa tunggu alumni mendapatkan pekerjaan

\begin{tabular}{lcc}
\hline Jenis Pekerjaan & Frekwensi & Prosentase \\
0-11 Bulan & 31 & $49.2 \%$ \\
12 bulan sampai 23 bulan & 23 & $36.5 \%$ \\
Lebih dari 23 bulan & 9 & $14.3 \%$ \\
Jumlah & 63 & $100 \%$ \\
\hline
\end{tabular}

Relevansi Kurikulum dengan Pekerjaan Alumni prodi PKO didapatkan data relevansi kurikulum dengan pekerjaan alumni diberikan pertanyaan sebanyak 5 buah, yang menghubungkan antara relevansi kurikulum dengan pekerjaan yang dijalani pada saat sekarang yaitu :

1. Perlukah pengembangan kurikulum Prodi PKLO ?. Pertanyaan tentang pentingnya peninjauan kurikulum kepada responden mendapat tanggapan yang positif dari keseluruhan responden. Sebanyak 2 orang responden atau $3.1 \%$ tidak mengisi, yang menganggap sangat tidak penting tidak ada atau 0 $\%$, yang menganggap tidak penting tidak ada $0 \%$, yang menganggap penting 21 orang atau 33.4 dan yang menganggap sangat penting $4063.5 \%$ orang.

2. Pertanyaan tentang relevansi antara kurikulum dengan pekerjaan saat ini ditanggapi beragam oleh alumni. Yang tidak memberi tanggapan 2 orang atau $3.1 \%$, yang menganggap sangat tidak penting 2 orang atau 3,1\%, Responden yang menganggap relevansi kurikulum dengan pekerjaan tidak penting sebanyak 3 orang atau $4.8 \%$ dan yang menganggap penting 16 orang atau $25.4 \%$ dan yang menganggap sangat penting sebanyak 40 orang atau 66.6.

3. Pertanyaan tentang relevansi perkuliahan dengan pekerjaan saat ini. Responden menanggapi relevansi perkuliahan dengan pekerjaan saat ini bervariasi sekali. responden yang tidak mengisi 2 orang atau $3,1 \%$, responden yang mengatakan sangat tidak penting 1 orang atau $1.6 \%$, yang menganggap tidak penting sebanyak 5 orang atau 
$7.9 \%$, yang menganggarp penting sebanyak 16 orang atau $25.4 \%$ dan yang menganggap sangat penting sebanyak 39 Orang atau $62 \%$.

4. Pertanyaan kesesuaian antara pekerjaan dengan cita cita.Responden telah menjawab tentang relevansi antara pekerjaan dan cita cita semasa masih kuliah. Hasilnya adalah dua orang atau 3,1\% tidak menjawab. Satu orang atau $1.6 \%$ menjawab sangat tidak penting, Tiga orang atau $4.7 \%$ orang menjawab penting, Sebanyak 24 orang responden atau $38 \%$ menjawab penting dan sebanyak 34 orang responden atau $54 \%$ menjawab sangat penting.

5. Pertanyaan perlunya masukan dari Alumni sebagai umpan balik.Sebanyak 63 orang responden telah mengisi kuesioner, sebanyak 2 orang atau 3.1 $\%$ responden tidak menjawab, responden yang menjawab sangat tidak penting tidak ada atau $0 \%$, Responden yang menjawab tidak penting tidak ada atau $0 \%$, menjawab penting sebanyak 18 orang 28.6 $\%$ sebanyak 43 orang responden atau $68 \%$ menjawab sangat penting. 5). Masukan dari alaumni dengan cara mengisi di isian bebas dengan hasil : Mayoritas alumni Prodi PKO menginginkan pengembangan jurusan agar meningkatkan diri supaya lebih baik lagi. Di samping itu alumni juga berharap agar kurikulum selalu ditinjau untuk selalu menyesuaikan dengan perkembangan jaman.

\section{SIMPULAN}

Berdasarkan analisis data yang telah dilakukan didapat simpulan sebagai berikut : 1). Hasil penelitian tracer studi ini didapat data tentang alumni yang terdiri dari jenis pekerjaan, lama studi, lama masa tunggu pekerjaan, relevansi kurikulum dan pekerjaan serta maasukan dari Alumni. 2) Mayoritas responden mengusulkan ada penelitian tentang tracer study yang diadakan secara berkala agar mereka dapat menyumbangkan tenaga dan pikirannya. 3) Mayoritas responden mengusulkan adanya rekonstruksi kurikulum agar Program studi selalu dapat mengembangkan diri dan dapat menjawab tantangan perkembangan jaman. 4) Program studi Pendidikan Kepelatihan Olahraga sangat membutuhkan Tracer Study untuk mendapatkan umpan balik dari alumninya dan dari stake holder lulusan.
Sedangkan saran yang diajukan adalah : 1) Setiap perguruan tinggi, Fakultas maupun Program Studi sebaiknya menyelenggarakan penelitian tracer study untuk mendapatkan umpan balik dari alumni maupun dari stake holder. 2) Data yang terkumpul melalui responden dihimpun dan disimpan untuk dijadikan acuan dalam penyusunan dan penyempurnaan visi, misi dan tujuan program studi. 3) Penelitian tracer pada program studi seharusnya dilakukan secara teratur dan berkelanjutan untuk mengantisipasi perkembangan jaman. 4) Masukan dari Alumni maupun stake holder dapat dijadikan sebagai acuan untuk pengembangan Perguruan tinggi, fakultas maupun program studi.

\section{DAFTAR PUSTAKA}

Danim, Sudarwan. 2000. Metode Penelitian untuk Ilmu-Ilmu Perilaku. Jakarta: Bumi Aksara.

Davis, B.D. \& Miller, T.R, 1996, "Job Preparation for The 21st Century: A Group Project" Journal of Education for Business, 72, (2), 6973.

Dharma, Surya. 2008. Pendekatan, Jenis dan Metode Penelitian Pendidikan.Jakarta : Dirjen PMPTK Depdiknas

Masri Singarimbun \& Sofian Effendi (ed.). 1995. Metode Penelitian Survai. Jakarta: LP3ES. Cetakan 2

McMillan, J.H. and Schumacher, S. 2001. Research in Education. New York: Longman, Inc.

Setneg. 2010. Mengharmoniskan Tenaga Kerja dan Pendidikan di Indonesia. Diunduh dari http//www.setneg.go.id.

Setiawan, B. dan A. Muntaha. 2000. Metode Penelitian Komunikasi II. Pusat Penerbitan Universitas Terbuka. Jakarta. 
Sudjana, N. dan Ibrahim, R. 2001.Penelitian dan Penilaian Pendidikan,Bandung: Sinar Baru Algesindo.

Sudjana, Nana. 2001. Tuntunan Penyusunan Karya Ilmiah. Bandung: Sinar Baru Algesindo.

Suharti, L.2011. Penilaian pihak Pengguna terhadap hardskill dan soft skill Sarjana Ekonomi. Jurnal MEGADIKMA vol 4 (2) 229-239
Sukardi. 2003. Metodologi Penelitian Pendidikan (Kompetensi dan Praktiknya). Jakarta: Bumi Aksara.

Sukmadinata, Nana Syaodih. 2005. Metode Penelitian Pendidikan. Bandung:Remaja Rosdakarya. 